\title{
KLONING PROMOTER $\beta$-AKTIN DARI IKAN GURAMI (Osphronemus gouramy)
}

\author{
Estu Nugroho", Alimuddin"), Anang Hari Kristanto", dan Odang Carman"*) \\ *) Balai Riset Perikanan Budidaya Air Tawar \\ Jl. Raya Sempur No. 1, Bogor \\ E-mail: estunugro@yahoo.co.uk \\ **) Departemen Budidaya Perairan-FPIK, Institut Pertanian Bogor \\ Jl. Lingkar Kampus, Kampus IPB Darmaga, Bogor 16680
}

Naskah diterima: 3 Januari 2009; Diterima publikasi: 2 April 2009

\begin{abstract}
ABSTRAK
Penelitian ini dilakukan untuk mengisolasi promoter $\beta$-aktin (ggBA) dari ikan gurami (Osphronemus gouramy). Sekuens promoter ggBA diisolasi menggunakan metode "degenerate" PCR. Sekuensing dilakukan menggunakan mesin ABI PRISM 3100-Avant. Analisis sekuens menggunakan program BLAST, GENETYX versi 7 dan TFBind. Panjang sekuens DNA hasil kloning adalah sekitar 2,2 kb. Analisis BLAST menunjukkan bahwa sekuens DNA hasil kloning memiliki kemiripan dengan sekuens gen $\beta$-aktin ikan yang ada di Bank Gen. Sekuens hasil kloning memiliki faktor transkripsi yang konserf untuk promoter $\beta$-aktin, yaitu: CCAAT, CC(A/T) ${ }_{6} \mathrm{GG}$, dan boks TATA. Posisi faktor transkripsi tersebut juga mirip dengan yang dimiliki oleh promoter $\beta$-aktin dari ikan yang ada di Bank Gen. Dengan demikian dapat disimpulkan bahwa fragmen DNA hasil amplifikasi PCR tersebut merupakan sekuens promoter $\beta$-aktin ikan gurami.
\end{abstract}

KATA KUNCI: kloning, promoter $\beta$-aktin, gurami, degenerate PCR

ABSTRACT: $\quad$ Cloning of $\beta$-actin promoter from giant gouramy (Osphronemus gouramy). By: Estu Nugroho, Alimuddin, Anang Hari Kristanto, and Odang Carman

The research was aimed to isolate $\beta$-actin promoter of gouramy ( $g g B A)$. Sequence of ggBA promoter was isolated using "degenerate" PCR. Sequencing was conducted using $A B I$ PRISM 3100-Avant machine. The sequencing analysis was done using BLAST, GENETYX ver 7 and TFBind programs. The sequencing length of DNA clone result was around $2.2 \mathrm{~kb}$. BLAST analysis showed that sequences from cloned DNA had the resemblence to those of $\beta$-actin sequences in GenBank database. The cloned sequences had transcript factors which followed $\beta$-actin promoter namely CCAAT, CC $(A / T)_{6} G G$ and TATA box.

KEYWORDS: cloning, $\beta$-actin promoter, degenerate PCR, transcription factor, Osphronemus gouramy

\section{PENDAHULUAN}

Promoter merupakan sekuens DNA yang terletak di bagian terminal 5 (upstream) yang berfungsi mengatur ekspresi suatu gen. Sekuens regulator ini sangat diperlukan dalam transgenesis. Umumnya penggunaan promoter yang bukan berasal dari ikan menghasilkan ekspresi transgen yang rendah atau bahkan tidak ada ekspresi (Chourrout et al., 1990). Penggunaan promoter dari ikan telah dibuktikan memiliki aktivitas lebih tinggi 
dalam mengatur ekspresi transgen dibandingkan dengan yang berasal dari mamalia atau virus pada ikan transgenik (Alam et al., 1996; Hanley et al., 1998; Alimuddin, 2003).

Salah satu jenis promoter yang memiliki aktivitas tinggi pada otot dan selalu aktif adalah promoter $\beta$-aktin. Promoter $\beta$-aktin telah diisolasi dari beberapa jenis ikan dan dilaporkan sebagai regulator dengan aktivitas tinggi dalam mengatur ekspresi transgen pada ikan transgenik. Promoter $\beta$-aktin telah diisolasi dari ikan mas Cyprinus carpio (Liu et al., 1990), ikan medaka Oryzias latipes (Takagi et al., 1994), ikan zebra Danio rerio (Higashijima et al., 1997), ikan mud loach Misgurnus mizolepis (Noh et al., 2003), ikan nila (Hwang et al., 2003; Anna, 2008), dan ikan kerapu tikus (Alimuddin et al., 2007). Promoter $\beta$-aktin dari ikan medaka mampu mengatur ekspresi gen penanda LacZ pada embrio ikan medaka (Takagi et al., 1994). Ekspresi gen GFP yang kuat dengan menggunakan promoter $\beta$-aktin medaka juga telah ditunjukkan pada ikan medaka (Hamada et al., 1998) dan rainbow trout (Yoshizaki, 2001). Selanjutnya, promoter ini juga aktif mengatur ekspresi gen pengkode enzim D6desaturase pada ikan zebra (Alimuddin et al., 2005) dan gen pengkode hormon pertumbuhan pada ikan nila (Kobayashi et al., 2007). Promoter $\beta$-aktin ikan mas mampu mengatur ekspresi beberapa gen penanda pada beberapa jenis ikan (Liu et al., 1990; Moav et al., 1993; Hwang et al., 2003). Sementara itu, promoter $\beta$-aktin dari ikan zebra dilaporkan aktif mengatur ekspresi gen GFP pada ikan zebra (Higashijima et al., 1997).

Panjang sekuens dan elemen yang ada pada promoter sangat menentukan tingkat aktivitasnya. Walaupun promoter $\beta$-aktin dari suatu spesies mampu mengatur ekspresi gen asing pada beberapa spesies lain, hingga saat ini belum diketahui promoter $\beta$-aktin dari jenis ikan mana yang lebih baik karena panjang sekuens dan elemen yang digunakan oleh setiap peneliti berbeda-beda. Hwang et al. (2003) baru-baru ini mencoba untuk membandingkan aktivitas promoter $\beta$-aktin dari ikan nila dan ikan mas. Panjang sekuens promoter (1,5 kb untuk ikan mas dan 1,6 kb pada ikan nila) dan elemen yang digunakan relatif sama; keduanya memiliki elemen CCAAT, CC(A/ T) ${ }_{6} \mathrm{GG}$ atau disebut motif CArG, dan boks TATA. Uji aktivitas promoter dengan gen penanda LacZ menunjukkan bahwa promoter $\beta$-aktin ikan nila (famili Cichlidae) lebih baik daripada ikan mas (famili Cyprinidae) bila digunakan pada ikan nila, tetapi hasil sebaliknya diperoleh bila digunakan pada ikan zebra (famili Cyprinidae). Hasil penelitian Hwang dan koleganya memperkuat dugaan bahwa penggunaan promoter dari spesies yang sama atau dari yang sekerabat adalah lebih baik. Pada artikel ini kami melaporkan hasil kloning promoter $\beta$-aktin dari ikan gurami (Osphronemus gouramy) dalam rangka pembuatan konstruksi gen all-gurami untuk pembuatan ikan gurami transgenik. Konstruksi gen dengan promoter dan gen penyandi protein tertentu dari ikan gurami disebut sebagai konstruksi gen all-gurami. Penerimaan konsumen diduga akan lebih baik pada ikan transgenik yang dibuat menggunakan konstruksi gen dengan promoter dan gen dari ikan, khususnya yang berasal dari spesies yang sama dibandingkan dengan yang berasal dari mamalia atau virus (Maclean \& Laight, 2000). Selain itu, penggunaan konstruksi gen all-gurami diduga dapat menjaga biodiversitas plasma nutfah bila terjadi pemijahan dengan populasi alam.

\section{BAHAN DAN METODE}

\section{Isolasi DNA Genomik dan Amplifikasi PCR}

DNA genomik diekstraksi dari jaringan hati ikan gurami menggunakan kit isolasi DNA Puregene (Gentra, Minneapolis, USA) dengan prosedur yang ada. Sekuens promoter $\beta$-aktin ikan gurami, disingkat menjadi ggBA, diisolasi menggunakan metode "degenerate" PCR dengan primer yang didesain berdasarkan database di Bank Gen seperti yang telah dijelaskan dalam Alimuddin et al. (2007). Primer yang digunakan adalah forward "F-BA" (5'GTGAGTGACGCCGGAC-CAATC-3') dan reverse "R-BA" (5'-TAGAAGGTGTGRTGCCAGATCTTC3'). Amplifikasi PCR menggunakan LA Taq polymerase (Takara Bio, Shiga, Japan) dengan program, yaitu pre-denaturasi pada suhu $94^{\circ} \mathrm{C}$ selama 3 menit; 5 siklus pada suhu $94^{\circ} \mathrm{C}$ selama 30 detik dan $62^{\circ} \mathrm{C}$ selama 3 menit; 30 siklus pada suhu $94^{\circ} \mathrm{C}$ selama 30 detik, $58^{\circ} \mathrm{C}$ selama 30 detik dan $72^{\circ} \mathrm{C}$ selama 3 menit; serta 1 siklus pada suhu $72^{\circ} \mathrm{C}$ selama 3 menit. Pengecekan hasil amplifikasi PCR dilakukan dengan elektroforesis menggunakan gel agarosa $0,7 \%$. Fragmen DNA hasil amplifikasi PCR diisolasi dari gel menggunakan kit purifikasi DNA (MoBio Laboratories, CA, USA) sesuai prosedur yang ada. 


\section{Ligasi Fragmen DNA, Transformasi dan Seleksi Koloni Bakteri}

Fragmen DNA hasil purifikasi dari gel diligasi dengan vektor kloning pGEM-T Easy (Promega, WI, USA) seperti yang dijelaskan sebelumnya dalam Alimuddin et al. (2007). Plasmid DNA hasil ligasi disebut sebagai pT-ggBA. Transformasi plasmid pT-ggBA ke dalam sel kompeten E. coli $\mathrm{DH}-5$ a dilakukan menggunakan kejutan panas pada suhu $42^{\circ} \mathrm{C}$ selama 45 detik. Bakteri hasil transformasi dipulihkan dalam media SOC dan dikultur selama 1 jam pada suhu $37^{\circ} \mathrm{C}$. Selanjutnya, bakteri disebar dalam cawan Petri yang mengandung gel agarosa $2 \times Y T$ dan diinkubasi selama semalam. Koloni bakteri yang membawa plasmid pT-ggBA diseleksi menggunakan metode "cracking" seperti dijelaskan dalam Alimuddin et al. (2007). Koloni bakteri yang membawa plasmid pT-ggBA dikultur menggunakan media cair 2 XYT selama semalam untuk digunakan dalam isolasi plasmid.

\section{Isolasi Plasmid, Sekuensing, dan Analisis Sekuens Promoter $\beta$-aktin}

Isolasi plasmid dilakukan menggunakan kit FlexiPrep (Amersham Biosciences, NJ, USA) dengan prosedur yang ada. Amplifikasi PCR untuk sekuensing plasmid pT-ggBA dilakukaN menggunakan sistem BigDye dengan primer "T7-BS" (5'-TTGTAATACGACTCACTATAGGGCGAA-3') atau DyeT-R (5'GGAATTGTGAGCGGATAACA-3'). Program PCR yang digunakan yaitu pre-denaturasi pada suhu $96^{\circ} \mathrm{C}$ selama 2 menit, dan 30 siklus dengan suhu $96^{\circ} \mathrm{C}$ selama 10 detik, $55^{\circ} \mathrm{C}$ selama 5 detik dan $60^{\circ} \mathrm{C}$ selama 3 menit. Sekuensing DNA dilakukan menggunakan mesin ABI PRISM 3100-Avant Genetic Analyzer. Analisis sekuens menggunakan software BLAST, GENETYX versi 7 dan TFBind.
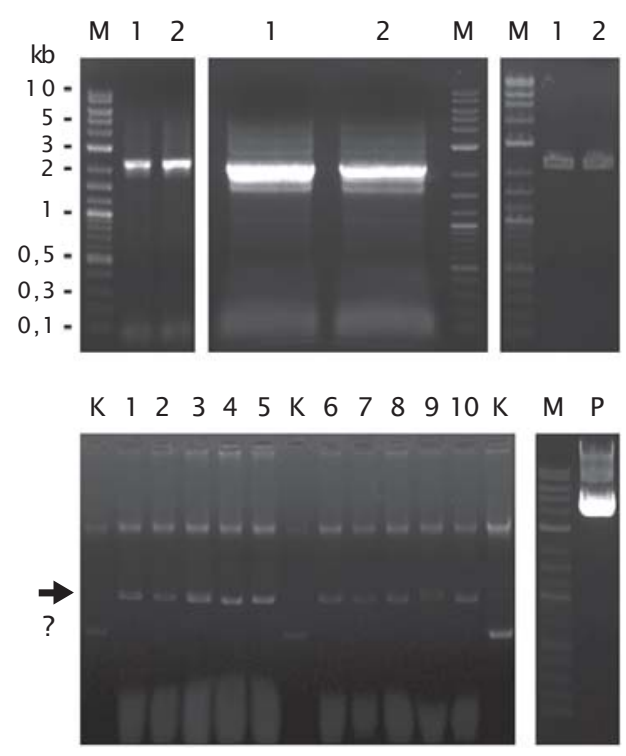

Gambar 1. Elektroforesis hasil amplifikasi PCR (gambar atas-kiri dan tengah) dan hasil purifikasi DNA dari gel (gambar atas-kanan). 1 dan 2 adalah nomor sampel. M adalah marker DNA 2-log ladder 0,1-10,0 kb (BioLabs Inc., New England). Elektroforesis hasil cracking (gambar bawah-kiri) dan plasmid pT-ggBA (gambar bawah-kanan). 1-10 merupakan nomor koloni bakteri putih yang membawa insersi (tanda panah); K adalah koloni biru tanpa insersi sebagai kontrol (tanda kepala panah); dan P adalah plasmid pT-ggBA.

Figure 1. Electrophoresis of PCR amplification product (left-above and middle) and DNA purification result from the gel (right-above). 1 and 2 are sample numbers. $M$ was 2-log ladder DNA marker, $0.1-10.0 \mathrm{~kb}$ (BioLabs Inc. New England). Electrophoresis of the cracking product (left-bottom) and pT-ggBA(right-bottom). The number of the inserted carried bacteria (arrow sign) was 1 to $10, \mathrm{~K}$ was the blue colony without insertion and P was $P T-g g B A$ 


\section{HASIL DAN BAHASAN}

Panjang fragmen DNA ikan gurami hasil amplifikasi PCR menggunakan primer F-BA dan RBA adalah sekitar 2 kb (Gambar 1, atas-kiri). Fragmen DNA hasil purifikasi dari gel (Gambar 1, atas-kanan) diligasi dengan vektor kloning, ditransformasi ke sel kompeten E. coli dan kemudian bakteri dikultur. Dengan melakukan elektroforesis terhadap hasil cracking untuk bakteri koloni berwarna putih, diketahui bahwa semua koloni bakteri tersebut membawa DNA insersi yang ditandai dengan ukuran pita DNA hasil elektroforesis lebih besar dibandingkan dengan kontrol koloni biru "K" (Gambar 1, bawah-kiri). Sejalan dengan hasil cracking, ukuran pita plasmid DNA hasil isolasi dari bakteri koloni putih lebih besar (Gambar 1, bawah-kanan) dibandingkan dengan ukuran vektor kloning pGEM-T Easy (3015 bp). Hal ini menunjukkan bahwa plasmid DNA bakteri tersebut mengandung DNA insersi hasil amplifikasi PCR.

Hasil sekuensing terhadap DNA insersi tersebut ditunjukkan pada Gambar 2 dan 3. Panjang sekuens hasil sekuensing dari arah forward adalah 1.262 bp (Gambar 2), sementara dari arah reverse adalah 1.202 bp (Gambar 3). Bagian ujung sekuens dari kedua hasil sekuensing tersebut yang memiliki kesamaan yang tinggi adalah sepanjang 248 bp.

5'-

gtgagtgacgccggaccaatcagcgggcgcgattccgaaagtttaccttttatggctcga gccgggcatctga cgcggtataaaagacgagcgcccacagctaacggaTTCACTCTGAGC GCCGTCACACGCAGCTTGTGCGGAATATCATTTGCCTGAAACCGGTTCCCTTAAAGCGAA AAACCCCCCCCACCCAAGgtaaggcgactggaactagtactgaaatatt tctaattctag agca atatt taataagtaaataatgg cttgtgtgttttttaatgcaactgactgttaaat gtgtcattt tgat tggaaaaaagacgtgagtgaccacgaggttctttgtctggccataca ccaa taatt taacttaaagcttttaaaaatc tataa ttaaaattgatactactatttg ta ttttgcggg tatttttg taagagtgtgcagt aatga tgactagagaccgcaaaacttgga acacaggtgcctttgga tggagccggcttaa tgaataacggtccctcctaagt taattat tctacttaaactggctcgtccttgtgtggttgtgcagatttgttcagctttcagctccgg ccctgtgtgccttttattcccagcagagtagttttaaagcggctttcgagttgagattgt ctggattccggctcttctccctttgtgcgcc cgatgcggcggggtgtgacctactttagc atat tagct tagc caca tcatgctaacaccgcccttcagacttgcaacc caagcaattt attaataat tatattttaattaacagccatgttcacttactgggcgtggtaacgctcac attatcatctgaa taactaactgtaaggcttcctttaaatggact tgcgcatagaggcct gcaa aaaagcaca aaatgaataattg tctaattgagtcgttggaccggtttttctacatg atgactccacgtcttgtcaact tgctgaggaaaagggggaaactgcacatcacccact tc ttaggaaaggcgtgctt tcagaaatgaagca tcagt caaggacttgtgacccattcatga gtcaacacagttcatttatgcacttaatttccctcttctg taattaaaagccagcagtgt gcagttaaagctggtgcaggagcttttggaaactgaacttacacgtgtagactttgtagt ctggtggaggagccgctgtgcatgaa tgggtgtcgaggatgacgcaatgttttggggcaa aa-' 3

Gambar 2. Sekuens genomik $\beta$-aktin ikan gurami hasil sekuensing dari arah depan. Huruf kecil adalah intron, sementara huruf besar adalah ekson 1. Huruf kecil yang ditulis tebal dalam kotak merupakan primer forward. Huruf kecil digarisbawahi merupakan elemen konserf CCAAT, CC(A/T) 6 GG dan boks TATA boks

Figure 2. Genomic sequence of gouramy $\beta$-actin from forward direction. Lowercase letters are intron, while the uppercase are exon. The lowercases, inside the box and written in bold are forward primer. The underlined lowercases are CCAAT, CC(A/T)6CG dan TATA box elements 
5 -

actgcacatcacccactcctagaaagcgtgcttcagaatgagcatcagtcagac ttgtgaccatcatgagtcacacagtcatatgcactattccctcttctgtataaa agccagcagtgtgcagttaaaggctggtgcaggagcttttgaaactgaaactta caacgtgtagacttgtagtcgtgtgtgaggagccgctgtgcaatgaatggcgtg gtcgaggatgacgcagtgatatgaggcaaagacgtcttatgcagattaaaccta caaattgctcaagaatgaggtggcagagggggaagctggctgcagtgagcctg gaggaagcggtcgctcagcggccggtctgataacgccttcctcgctgcgctctg ccgctctggcctgcgccatggcgccggtagccgcaaagctgctcaaaaccgaac catgtccttatatggtaacaacagaacgcagcgccacttccttttgtctgctcg ggcggaatgtgggtccacagcgccaccgagcggctcctctggtgaactgcaggc gactgagtcaacaggaagtgagggctcggagtgtcgtggcggatgtgagacttg agtattcaacgcttctcttctt taactttctctcttaacagTACAACCATGGAT GATGAAATCGCCGCACTCGTTGTTGACAACGGATCCGGTATGTGCAAAGCCGGA TTCGCCGGTGACGACGCCCCCCGTGCTGTCTTCCCCTCCATCGTCGGTCGCCCC AGGCATCAGgtgagtgacggatcttaattagaatgaacacaaactcctgactgg ctaactagaacttgaatacacaatatt tacaagtattgaagtaattcttaatt tataagctccagtgtatatacatcgattatgtaattacaggggagctgttagtg tttt tattaatgcataaatttaagtgcatgtaagcacatt tcactggatagtt agaaacactgacatgtgcctatgtttaaatactcaaattatgtttggcagtgtc tcaccttaagttctccaatttgttcagGGAGTGATGGTGGGTATGGGCCAGAAG GACAGCTACGTTGGTGATGAAGCTCAGAGCAAGAGAGGTATCCTGACTCTGAAG TACCCCATCGAGCACGGTATTGTGATCAACTGGGATGACATGGAGAAGATCGGC ACCACACCTTCTA-' 3

Gambar 3. Sekuens genomik $\beta$-aktin ikan gurami hasil sekuensing dari arah reverse. Huruf kecil adalah intron, sementara huruf besar adalah ekson 2 dan 3. Kodon awal ATG (ditulis tebal) terletak pada epson 2. Huruf besar ditulis tebal dalam kotak merupakan primer reverse. Huruf kecil digaris bawahi merupakan elemen $\mathrm{CC}(\mathrm{A} / \mathrm{T})_{6} \mathrm{GG}$

Figure 3. Sequence of gouramy $\beta$-actin genomic from reverse direction. Lowercase letters are intron, while the uppercases are exon 2 and 3. Initial codon ATG (written in bold) located on exon 2, The uppercases, inside the box and written in bold are reverse primer. The underline lowercases are CC $(A / T) 6 G G$ elements

Meskipun perlu sub-kloning untuk mengetahui secara pasti, berdasarkan alignment antara sekuens arah forward dan reverse, panjang sekuens hasil kloning adalah sekitar 2,2 kb (Gambar 4), mirip dengan panjang fragmen DNA hasil amplifikasi PCR (Gambar 1, atas-kiri). Panjang sekuens hasil sekuensing dari arah forward disajikan pada Gambar 2. dan dari arah reverse disajikan pada Gambar 3.

Alignment antara sekuens arah forward dan reverse, panjang sekuens hasil kloning disajikan pada Gambar 4.
Untuk mengetahui apakah sekuens yang diperoleh mirip dengan suatu gen atau genom yang ada di Bank Gen, dilakukan analisis BLAST (Basic Local Alignment Search Tool). Hasil analisis menunjukkan bahwa sekuens tersebut sangat mirip dengan gen $\beta$-aktin dari berbagai jenis ikan seperti ikan nila dan ikan mas (hasil tidak ditampilkan). Dengan menggunakan program TFBind, diketahui bahwa sekuens hasil kloning memiliki sekuens konserf (conserve sequence) bagi promoter $\beta$-aktin, yaitu CCAAT dan boks TATA (Gambar 5). Hasil 


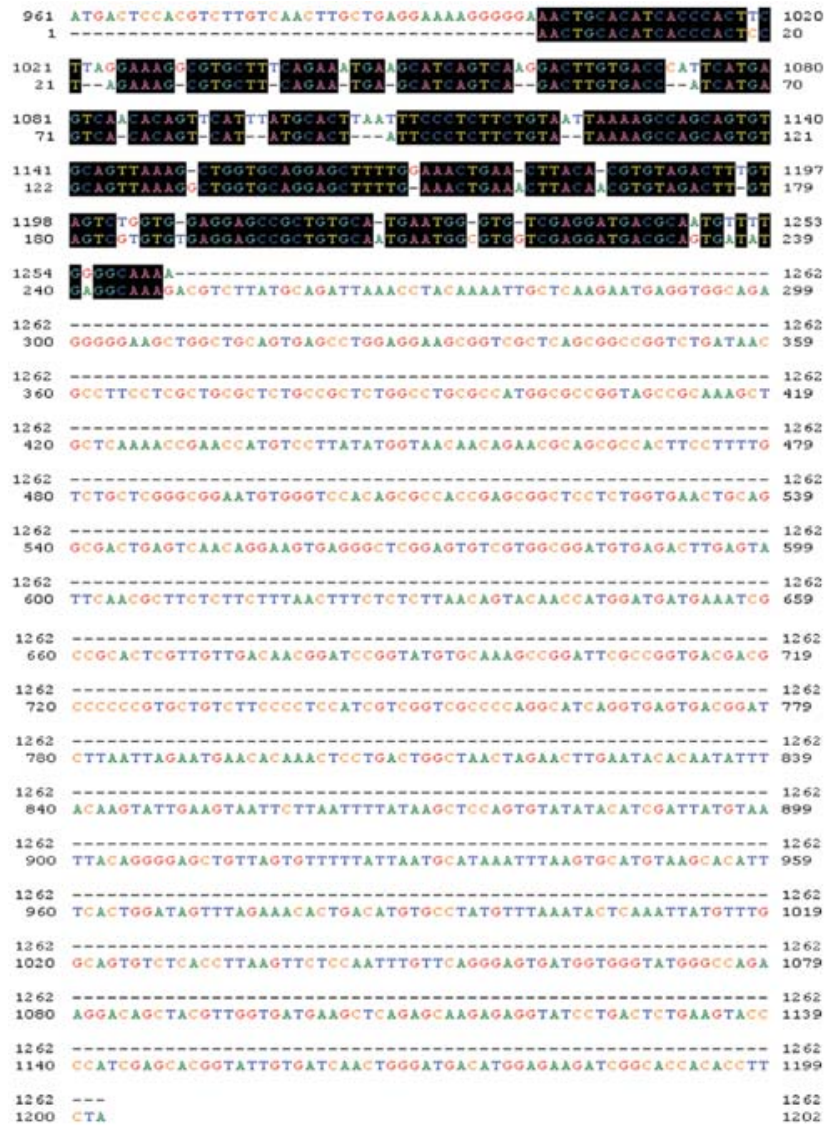

Gambar 4. Alignment sekuens DNA genomik $\beta$-aktin ikan gurami hasil sekuensing dari arah forward (atas) dan reverse (bawah). Bagian ujung masing-masing sekuens forward (ujung 3') dan reverse (ujung 5') memiliki persamaan yang cukup tinggi. Panjang sekuens hasil amplifikasi PCR mirip dengan panjang sekuens hasil sekuensing, yaitu $2,2 \mathrm{~kb}$. Panjang sekuens arah forward $1.262 \mathrm{~kb}$, arah reverse $1.202 \mathrm{~kb}$, dan bagian sekuens yang sama sepanjang $248 \mathrm{bp}$

Figure 4. Sequence alignment of gouramy DNA of $\beta$-actin genomic from forward direction (above) and reverse (bottom). Each tail part of forward sequence (3' tail) and (5' tail) have the highest similarity. The sequence of PCR amplification length is similar to the sequence length of the sequencing result which is $2.2 \mathrm{~kb}$. The sequence length from forward direction is $1,262 \mathrm{~kb}$, reverse direction 1,202 $\mathrm{kb}$ and the similar sequence part $248 \mathrm{bp}$

analisis sekuens dengan menggunakan program TFBind disajikan dalam Gambar 5.

Posisi sekuens konserf tersebut adalah mirip dengan yang ada di dalam sekuens promoter $\beta$-aktin ikan-ikan yang ada di Bank Gen. Selain itu, dengan membandingkan sekuens hasil sekuensing dengan sekuens promoter $\beta$-aktin beberapa jenis ikan yang ada di database menggunakan program GENETYX, diketahui bahwa sekuens hasil kloning juga memiliki sekuens konserf CC(A/T $)_{6} \mathrm{GG}$ atau CArG (Gambar 2 dan 3). Sekuens promoter $\beta$ aktin ikan gurami memiliki 2 sekuens CArG dengan posisi seperti promoter $\beta$-aktin ikan pada umumnya, yaitu terletak antara faktor transkripsi CCAAT dan boks TATA, dan dalam intron 1 dekat sekuens ekson 2. Posisi sekuens CArG adalah seperti yang terdapat pada promoter $\beta$-aktin dari ikan lainnya (Noh et al., 2003), manusia, tikus dan ayam (Orita et 


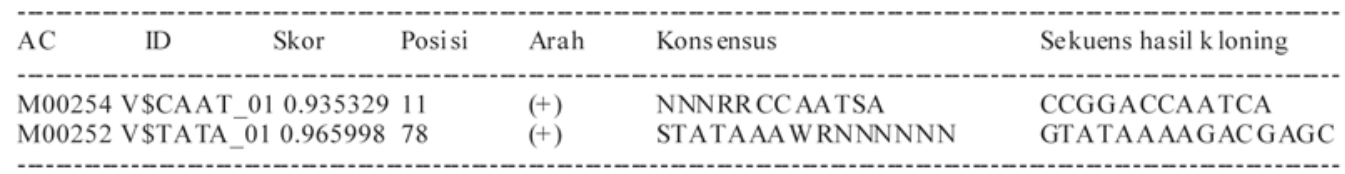

Gambar 5. Hasil analisis TFBind. Sekuens hasil kloning memiliki skor kemiripan dengan sekuens konsensus masing-masing sebesar 93,5\% dan 96,6\% untuk CCAAT dan boks TATA

Figure 5. TFBind analysis result. Cloning result sequence has similarity score with each concensus sequence of $93.5 \%$ and $96.6 \%$ for CCAAT and TATA box

al., 1989; Sands et al., 1993). Dengan demikian dapat disimpulkan bahwa sekuens promoter $\beta$-aktin ikan gurami adalah konserf secara evolusi (evolutionary conserved). Satu sekuens tambahan yang mirip CArG juga terdapat dalam intron 1 , yaitu CCTTTAAATCG.

Perlu penelitian lanjutan untuk mengetahui apakah sekuens tersebut juga menentukan tingkat aktivitas promoter $\beta$ aktin ikan gurami. nSekuens DNA hasil kloning memiliki 3 ekson (Gambar 2 dan 3). Posisi ekson-intron dalam sekuens mengikuti aturan GT-AG. Posisi ekson diduga menggunakan program GENETYX. Ekson 1 diduga terletak pada nukleotida (nt.) 109-198 dihitung dari ujung sekuens terminal 5 hasil

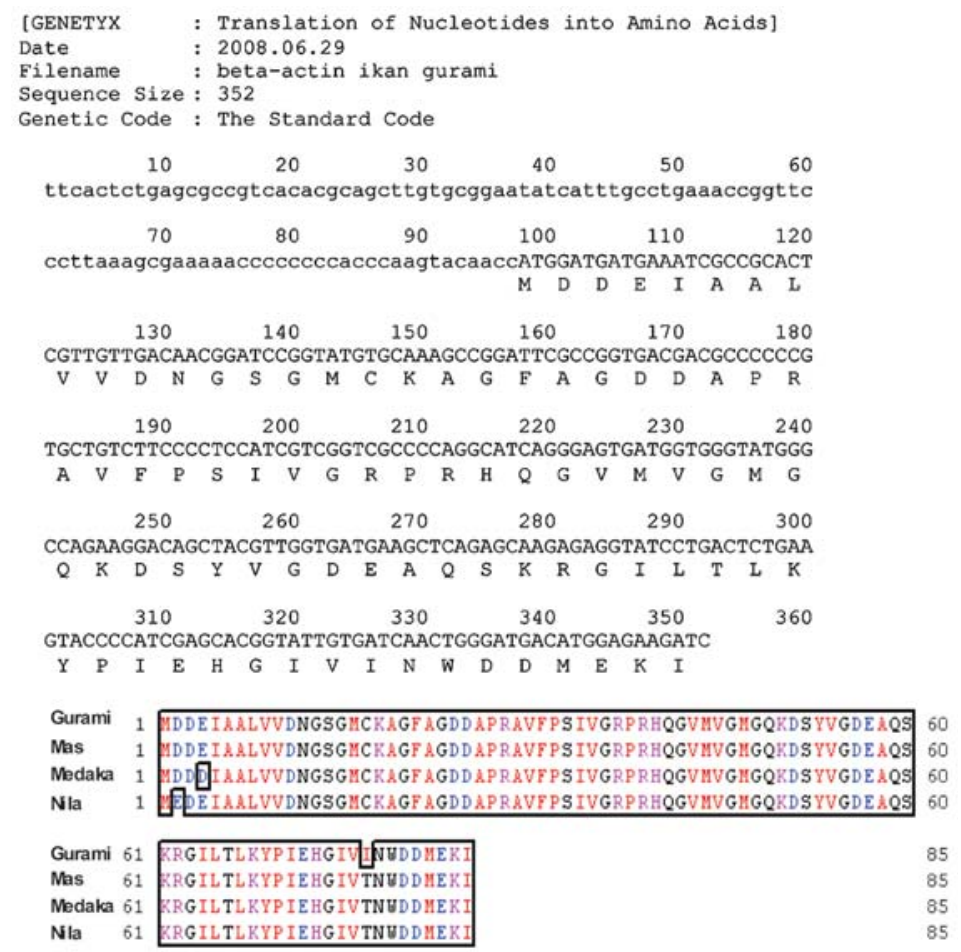

Gambar 6. Sekuens parsial gen $\beta$-aktin ikan gurami dan asam amino residu (gambar atas). Alignment asam amino residu gen $\beta$-aktin ikan gurami dengan ikan mas, medaka, dan ikan nila. Nomor aksesi Bank Gen b-aktin ikan mas M24113, ikan medaka S74868 dan ikan nila AY1 16536

Figure 6. Partial sequence of gouramy $\beta$-actin gen and amino acid residue (above). Alignment of amino acid of gouramy $\beta$-actin gen with common carp, medaka and nile tilapia. GenBank accession number of common carp is M24113, medaka S74868 and nile tilipia AY1 16536 
sekuens arah forward (Gambar 2). Ekson 2 terletak pada nt. 636-765, sementara sekuens parsial (sebagian) ekson 3 dimulai pada nt. 1.054 dihitung dari ujung sekuens terminal 5 arah reverse (Gambar 3). Ekson 1 merupakan sekuens tidak mengkodekan asam amino atau disebut unstranslated region. Posisi dan sekuensnya masih bersifat dugaan dan perlu dibuktikan dengan cara mengisolasi mRNA $\beta$-aktin. Selanjutnya, ekson 2 dan 3 merupakan sekuens yang mengkodekan asam amino. Kodon awal (ATG) terdapat pada ekson 2. Sekuens asam amino residu gen $\beta$-aktin ikan gurami (Gambar 6) memiliki kemiripan yang sangat tinggi dibandingkan dengan ikan mas, medaka dan ikan nila. Hal ini memperkuat dugaan bahwa sekuens DNA hasil isolasi merupakan sekuens $\beta$-aktin.

Sekuens promoter $\beta$-aktin ikan gurami hasil kloning memiliki faktor-faktor transkripsi spesifik yang biasa ditemukan pada promoter $\beta$-aktin ikan, yaitu CCAAT, CC(A/T) ${ }_{6} \mathrm{GG}$ atau motif CArG, dan boks TATA. Dengan demikian sekuens hasil kloning diduga memiliki aktivitas yang sama dengan promoter $\beta$-aktin ikan yang telah diuji sebelumnya seperti ikan medaka. Hubungan tingkat aktivitas promoter $\beta$-aktin dengan sekuens CCAAT telah diteliti oleh Quitschke et al. (1989). Kegunaan motif CArG, sebagai elemen responsif terhadap serum (serum-response element) telah dijelaskan oleh Liu et al. (1991). Elemen CArG kedua juga berpengaruh positif terhadap aktivitas promoter (Liu et al., 1990). Boks TATA merupakan elemen yang umum dijumpai pada sekuens promoter, sebagai tempat RNA polimerase melekat (bind) pada saat transkripsi RNA akan berlangsung (Glick \& Pasternak, 2003).

\section{KESIMPULAN}

Promoter $\beta$-aktin dari ikan gurami telah berhasil diisolasi dengan panjang sekuens sekitar 2,2 kb. Elemen-elemen yang biasa terdapat pada promoter $\beta$-aktin, yaitu CCAAT, CArG dan boks TATA, juga ditemukan pada sekuens promoter $\beta$-aktin ikan gurami hasil kloning.

\section{UCAPAN TERIMA KASIH}

Penelitian ini biaya oleh Anggaran APBN Balai Riset Perikanan Budidaya Air Tawar 2008. Kami menyampaikan banyak terima kasih kepada Prof. Dr. Goro Yoshizaki (Laboratorium Fisiologi Ikan, Department of Marine
Biosciences, Tokyo University of Marine Sciences and Technology, Japan) atas bantuannya dalam sekuensing.

\section{DAFTAR ACUAN}

Alam, M.S., Lavender, F.L., lyengar, A., Rahman, M.A., Ayad, H.H., Lathe, R., Morley, S.D., \& Maclean, N. 1996. Comparison of the activity of carp and rat $\beta$-actin gene regulatory sequences in tilapia and rainbow trout embryos. Mol. Reprod. Dev., 45: 117-122.

Alimuddin. 2003. Introduction and expression of foreign D6-desaturase-like gene in a teleostean fish. Thesis. Tokyo University of Fisheries, Japan.

Alimuddin, Yoshizaki, G., Kiron, V., Satoh, S., \& Takeuchi, T. 2005. Enhancement of EPA and DHA biosynthesis by over-expression of masu salmon D6-desaturase-like gene in zebrafish. Transgenic Res., 14: 159-165.

Alimuddin, Nugrahani, W., Aliah, R.S., Sumantadinata, K., Faizal, I., Carman, O., \& Yoshizaki, G. 2007. Isolasi dan karakterisasi promoter $\beta$-actin dari ikan kerapu bebek (Cromileptes altivelis). J. Ris. Akuakultur, 2: 199-210.

Anna, O. 2008. Isolasi dan karakterisisasi promoter $\beta$-actin ikan nila (Oreochromis niloticus). Skripsi. Departemen Budidaya Perairan. FPIK, IPB.

Chourrout, D.R., Guyomard, R., \& Houdebine, L.M. 1990. Techniques for the development of transgenic fish: a review. In: Church RB (Ed.). Transgenic Models in Medicine and Agriculture. Wiley-Liss, New York, p. 89-99.

Glick, B.R. and Pasternak, V. 2003. Molecular Biotechnology: Principles and Application of Recombinant DNA. $3^{\text {rd }}$ ed. ASM Press, Washington, DC.

Hamada, K., Tamaki, K., Sasado, T., Watai, Y., Kani, S., Wakamatsu, Y., Ozato, K., Kinoshita, M., Kohno, R., Takagi, S., \& Kimura, M. 1998. Usefulness of the medaka $\beta$-actin promoter investigated using a mutant GFP reporter gene in transgenic medaka (Oryzias latipes). Mol. Mar. Biol. Biotechnol., 7: 173180.

Hanley, S., Smith, T.J., Muller, F., Maclean, N., Uzbekova, S., Prunet, P., \& Brenton, B. 1998. Isolation and functional analysis of the histone $\mathrm{H} 3$ promoter from Atlantic salmon (Salmo salar L.). Mol. Mar. Biol. Biotechnol., 7: 165-172. 
Higashijima, S., Okamoto, H., Ueno, N., Hotta, Y., \& Eguchi, G. 1997. High frequency generation of transgenic zebrafish which reliably express GFP in whole muscles or the whole body by using promoters of zebrafish origin. Dev. Biol., 192: 289-299.

Hwang, G.L., Rahman, M.A., Razak, S.A., Sohm, F., Farahmand, H., Smith, A., Brooks, C., \& Maclean, N. 2003. Isolation and characterisation of tilapia $\beta$-actin promoter and comparison of its activity with carp $\beta$ actin promoter. Biochimica et Biophysica Acta, 1,625: 11-18.

Kobayashi, S.I., Alimuddin, Morita, T., Miwa, M., Lu, J., Endo, M., Takeuchi, T., \& Yoshizaki, G. 2007. Transgenic Nile tilapia (Oreochromis niloticus) over-expressing growth hormone show reduced ammonia excretion. Aquaculture, 270: 427-435.

Liu, Z., Moav, B., Faras, A.J., Guise, K.S., Kapuscinski, A.R., \& Hackett, P.B. 1990. Functional analysis of elements affecting expression of the $\beta$-actin gene of carp. Mol. Cell. Biol., 10: 3,432-3,440.

Liu, Z., Moav, B., Faras, A.J., Guise, K.S., Kapuscinski, A.R., \& Hackett, P. 1991. Importance of the CArG box in regulation of $\beta$-actin-encoding genes. Gene, 108: 211 217.

Maclean, N. \& Laight, R.J. 2000. Transgenic fish: an evaluation of benefits and risks. Fish Fish, 1: 146-172.

Moav, B., Liu, Z., Caldovic, L.D., Gross, M.L., Faras, A.J., \& Hackett, P.B. 1993. Regulation of expression of transgenes in developing fish. Transgenic Res., 2: 153-161.
Noh, J.K., Cho, K.N., Han, E.H., Kim, A., Lee, J.S., Kim, D.S., \& Kim, C.G. 2003. Genomic cloning of mud loach Misgurnus mizolepis (Cypriniformes, Cobitidae) beta-actin gene and usefulness of its promoter region for fish transgenesis. Mar. Biotechnol., 5(3): 244-252.

Orita, S., Makino, K., Kawamoto, T., Niwa, H., Sugiyama, H., \& Kakunaga, T. 1989. Identification of a site that mediates transcriptional response of the human $\beta$-actin gene to serum factors. Gene, 30: 13-19.

Quitschke, W.W., Lin, Z.Y., DePoti-Zilli, L., \& Paterson, B.M. 1989. The $\beta$-actin promoter. J. Biol. Chem., 264: 9,539-9,546.

Rahman, M.A. \& Maclean, N. 1992. Fish transgene expression by direct injection into fish muscle. Mol. Mar. Biol. Biotechnol., $1: 286-289$.

Sands, A.T., Hansen, T.N., Demayo, F.J., Stanley, L.A., Xin, L., \& Schwartz, R.J. 1993. Cytoplasmic $\beta$-actin promoter produces germ cell and preimplantation embryonic transgene expression. Mol. Reprod. Dev., 34: 117-126.

Takagi, S., Sasado, T., Tamiya, G., Ozato, K., Wakamatsu, Y., Takeshita, A., \& Kimura, M. 1994. An efficient expression vector for transgenic medaka construction. Mol. Mar. Biol. Biotechnol., 3: 192-199.

Yoshizaki, G. 2001. Gene transfer in salmonidae: applications to aquaculture. Suisanzoshoku, 49: 137-142. 